Mord und Totschlag herrschen, sondern daß es - schon vor dem Eintreffen der Europäer - auch dort Strukturen politischer und rechtlicher Organisation gab, die den unbefangenen Leser sicherlich verblüffen und die ihm Bewunderung abnötigen würden. Nur so kann auch das nötige Gegengewicht gesetzt werden zu dubiosen „Expeditionsberichten“ im Fernsehen oder geradezu kriminellen Filmen wie „africa ama“.

Eigenartigerweise enthält das Buch zwar acht Seiten Fotografien, aber keine einzige Karte. Und obwohl es 1972 verlegt ist, schließt es im wesentlichen 1967/69 ab; bei einer Neuauflage sollte es wohl aktualisiert werden. Trotz dieser anzumerkenden Kritiken kann der Wert eines solchen ebenso fundiert wie anregend geschriebenen Buches nicht hoch genug eingeschätzt werden. Damit es allerdings diejenigen, die es erreichen sollte, auch tatsächlich erreicht, wird man es wohl übersetzen müssen.

Heinz Joachim Jacobsohn

\title{
WILlaRd R. JoHNSON
}

The Cameroon Federation: Political Integration in a Fragmentary Society

Princeton, New Jersey: Princeton University Press, 1970, Pp. 426

Victor T. LeVine

The Cameroon Federal Republic

Ithaca and London: Cornell University Press, 1971, Pp. 205

The Cameroon presents a special interest for those concerned with the problems arising from the division of Africa into Francophone and Anglophone areas of cultural influence. Here for the first time an attempt is being made to integrate two separate territories, one of which came under French colonial rule while the other experienced British rule. The process of integration, as might be expected, has not been easy. Johnson and Le Vine present us an account of this experiment which may be significant for the future of African unity in so far as the removal of linguistic and cultural barriers between English-speaking and French-speaking Africa may be the last but most difficult obstacle to complete unity.

The impetus for reunification in the Cameroon was derived from the Kamerun idea i. e. that despite the complex ethnic structure, Cameroon constituted one and the same nation which had been unjustly divided among the British and French who administered the two parts of the country, first, as mandated territories under the League of Nations and later, as trust territories under the United Nations. Thus the thirty years of German colonial rule (1884-1914) which was, like all colonial systems, characterized by harsh methods and inhuman treatment, became as Le Vine puts it, "an important touchstone for Cameroonian nationalists, a potent and evocative symbol of a half-mythical "golden age" when the Cameroon was one and undivided" (p. 6). The useful myth of Kamerun which found expression in the demand in both British and French Cameroon for reunification was utilized by various political groups who differed in their motives but were united in their desire to end colonial rule. These differences in motivation explain the confusing and contradictory politics which emerged in the period preceeding the indepence of the French territory (Republic of Cameroon, Jan. 1, 1960) and the reunification of both areas (Federal Republic of Cameroon, Oct. 1. 1961). 
The federation brought together peoples with divergent colonial experiences. The Easterners were accustomed to French language, culture, law and administration while the Westerners knew of the British way of life. The federal system was chosen because it seemed to be the best way of maintaining the cultural and linguistic diversity in a single country. Attempts at harmonization have so far not been particularly successful. English and French still remain the official language in the East and West, with few persons making the effort to learn both languages. The educational systems in both parts of the country are still basically based on French and English models and advocacy of bilingualism and biculturalism has not been matched by practical measures. The Federal University of Laoundé is French oriented and professors fluent in French and English are as rare in Cameroon as elsewhere. Harmonization of legal systems has not proceeded as fast as one may wish; the common law and the civil law traditions still run their independent courses, with the former in a weaker position. Though the new codes, eg. labour code, penal code, contain elements of both traditions, their structure is basically French. If little progress has been made in the direction of biculturalism and bilingualism, this is not entirely the fault of the Cameroonian authorities who have very limited means and have had insufficient time to effect the necessary changes. Moreover, the British and the French who are supposed to be helping in this cultural experiment have in fact been creating obstacles. Instead of the Cameroon becoming a melting pot for the various cultures, it has in many ways been a ground for neocolonialist rivalries and jealousies. Some Cameroonians, such as Dr. Pierre Ngijol, have suggested that the best way out of the Anglo/Francophone rivalry would be to develop one or more of the African languages into a national language. In the long run, this would be the most fruitful and respectable solution, not only for Cameroon but for all African countries. Here, we beg to differ from Professor Johnson when he declares that "there is also the equally real and extensive multilingualism of most Africans, which ought to make it evident to them that one can partake of several cultures at once without necessarily losing one's identity" (p. 81). While it may be true that an individual can participate in several cultures without losing his identity, we suggest that in the case of a nation, this is not so. Moreover, in the case of Africa, the foreign languages present are not competing on equal basis with the African languages. European languages assume a totalitarian and imperialistic position in so far as they threaten to drive out all the other languages if no preventive measures are taken. On the language question, we fully support the view expressed by Dr. Joseph Ki-Zerbo that "to accept the death of African languages is to commit cultural suicide" (cited by Johnson, p. 80). Many an African who has seriously considered the matter would share Dr. Ngijol's view, that language is not merely the means of expressing a civilization but "c'est la civilisation même" (cited by Johnson, p. 295).

One is often astonished by the assertion made by Europeans and some African intellectuals that African culture can be adequately expressed in European languages. Exponents of such a viewpoint hardly ever ask the question whether European culture could be adequately expressed in African languages. If they do, they are likely to come to a negative answer and, predictably, attribute this to the supposed inferiority or underdevelopement of African languages. They forget that language and culture are the response to specific historical and geographical circumstances of a people. It is not difficult to understand the European supporters of a universal culture, since quite often "universal" is used only to refer to the 
expansionist cultures of Europe. One could easily imagine that the cultural universalists would become particularists and would emphasize cultural diversity if say, African, Indian or Chinese culture threatened to engulf the remaining cultures. But how does one explain the position of those Africans who assert that English and French are universal languages, representing universal cultures in which all of us must participate and who conveniently forget that the expansion of these languages has been solely due to the force of arms and not to any inherent qualities? Johnson suggests that among the factors inhibiting the adoption of African languages as official languages are: their lack of technical or artistic literature; the need to retain easy access to the scientific, technical and cultural products of the "developed" world. In his view a new nation state "cannot be considered authentically modern except as it embodies the values and insights of the latest science and technology the European languages monopolize" (p. 81). It is sometimes also said that there is a certain emotional attachment to English and French on the part of African intellectuals. Our own view is that those who owe their position and social prestige to their acquisiton of European cultures and languages are not likely to advocate their replacement by African languages and cultures.

Whatever may have been the degree to which the Federation of Cameroon made accommodation for cultural pluralism, it is quite clear that in the political sphere, there was little desire for pluralism. The complex political picture of the pre-independence days changed gradually as the major parties set about to consolidate their position and eventually in September 1966 founded the Union Nationale Camerounaise (UNC) as the de facto national single party in the country. The UNC may be regarded as the enlargement of Ahidjo's Union Camerounaise (UC) by the absorption of the other parties: Kamerun National Democratic Party (KNDP), Cameroon Peoples National Convention (CPNC) and the Cameroon United Congress (CUC).

A particular feature of politics in Cameroon, at least in the East, is that the party which started the campaign against colonialism, the Union des Populations du Cameroun (UPC), never benefited from the fruits of independence. Founded in 1948 under the leadership of Reuben Um Nyobé, Felix Roland Moumié, Ernest Ouandié and Abel Kingué, the UPC entered into collision with the French colonial authorities who were disturbed by the militant Marxist tendencies displayed by the party. After strikes, revolts and other mass activites organized by the UPC, the colonial government carried out a massive action of repression and banned the party in July 1955. The militants took to the maquis, some of them going into exile in Accra, Conakry and Cairo. But even in exile, the UPC continued to be a major factor in Cameroonian politics between 1955-60. The party later became divided, its leaders were either killed (some in action, others poisoned), or won over by Ahidjo's Union Camerounaise. By 1970 when the last important UPC leader, Ernest Ouandié was captured, tried and hanged (1971), the party had ceased to be a major factor in Cameroonian politics.

Johnson and Le Vine based their books on the federal structure which, as a result of a referendum on 20th May 1972, was replaced by a unitary form of constitution. But both authors had clearly forseen the strong pull towards a unitary constitution (Johnson, p. 370, Le Vine, p. 94). The basic problems facing Cameroon have, of course, not been in anyway modified by the constitutional reform which legitimized the de facto constitutional practice.

K. Opoku 